\title{
Religious Discrimination and International Crises: International Effects of Domestic Inequality $^{1}$
}

\author{
ÖZg ÜR ÖZDAMAR \\ Bilkent University \\ AND \\ Yasemin Akbaba \\ Gettysburg College
}

\begin{abstract}
This paper explores religious discrimination against ethnic groups and foreign policy crisis linkages as part of the broader foreign policy approaches developed by McGowan and Shapiro (1973) and James and Ozdamar (2005, 2008). Informed by the literature suggesting that domestic policies of repression and inequality may result in similar patterns of behavior internationally, this study tests whether states characterized by high levels of religious discrimination against ethnoreligious minorities are more likely to initiate or become involved in foreign policy crises with other states in general. A broad range of data sources, including an independently collected religious discrimination index, are used to test the hypothesized relationship between religious discrimination and international crisis during the period 1990-2003. The results suggest that religious discrimination is an important predictor of initiating and becoming involved in international crises.
\end{abstract}

This article proposes a factor theory of religious discrimination against ethnoreligious minorities ${ }^{2}$ and foreign policy crisis linkages by improving on earlier foreign policy approaches developed by McGowan and Shapiro (1973) and James and Ozdamar $(2005,2008)$. We argue that a domestic environment of repression and inequality may result in similar patterns of foreign policy behavior and may eventually lead to interstate crises. The analysis draws upon previous studies focusing on identity-based discrimination in predicting foreign policy formation.

The ethnic conflict and feminist literatures have established connections between a state's unjust treatment of identity groups and that state's international behavior (Caprioli and Trumbore 2003a,b). The results provide support for the hypothesis that religious discrimination against ethnoreligious minorities at the domestic level increases that state's likelihood of involvement in and initiation of an interstate crisis.

This study contributes to the literature in three ways. First, despite the recognition of religion as an important component of policymaking, studies focusing on

\footnotetext{
${ }^{1}$ We thank Nükhet Ahu Sandal and the anonymous reviewers of FPA for their helpful comments on earlier drafts. Please note that the name ordering is reverse alphabetical and does not denote unequal contribution.

${ }^{2}$ Ethnoreligious minorities are ethnic minorities with a different religious identity than the majority of the population.

Özdamar, Özgür and Yasemin Akbaba. (2014) Religious Discrimination and International Crises: International Effects of Domestic Inequality. Foreign Policy Analysis, doi: 10.1111/fpa.12016

(C) 2013 International Studies Association
} 
how religion contributes to foreign policy decisions are new and limited in number (Warner and Walker 2011). We aim to fill this gap by using and expanding insights from the larger foreign policy analysis (FPA) literature. Second, theoretical foreign policy approaches (McGowan and Shapiro 1973; James and Özdamar 2005, 2008) that account for complex linkages in making foreign policy with case study approaches are exposed to statistical analysis and quantitative evidence. In this sense, this paper contributes to theory building in the FPA literature. Last, the paper uses comprehensive data on religious discrimination.

We begin by presenting a theoretical discussion of the domestic environment of inequality, religious discrimination, and foreign policy patterns as synthesized from the literature. Next, we present an approach to the study of foreign policy that incorporates international, state, and subnational considerations, with religious discrimination as an essential component. The research design, operationalization of variables, and results of the empirical analysis follow. We conclude with a brief summary of the findings and discuss their implications for policymakers and the literature.

\section{Regime Type, Religious Discrimination, and Foreign Policy}

There are many competing and integral explanations that focus on domestic political characteristics' effects on international behavior, such as the larger FPA literature on domestic politics and foreign policy linkages; democratic peace literature analyzing democratic states' engagement in militarized conflicts; and, most specifically, literature focusing on the question of whether a state's domestic injustices affect its international relations.

Foreign policy analysis as a subdiscipline of political science originated in the $1960 \mathrm{~s}$, around the same time as the so-called behavioral revolution in that field. The earliest examples of the discipline dealt with issues such as whether domestic political openness (or lack thereof) affected foreign relations (Rosenau 1966); the effect of national self-images (Rosenau 1966, 1987) or whether national role conceptions originating from domestic politics shaped foreign policy (Holsti 1970; Holsti and Rosenau 1996). Another classic study in this area focused on the decision-making dynamics of foreign policy making and argued that domestic political-bureaucratic bargaining and narrow institutional self-interests may shape a state's foreign policy (Allison 1969). According to the bureaucratic-politics model, the domestic political fight (court politics) determines foreign policy, and international policy is the sum of unintended consequences of domestic political competition. Whether any conclusion on domestic characteristics' effect on foreign policy can be reached from the FPA literature is mostly still under debate. An exception is the democratic peace theory, which provides evidence that regime type is related to foreign policy behavior, such as involvement in militarized conflict.

The ample body of research in the field of international conflict, however, has established general connections between states' domestic and foreign policies (Wilkenfeld 1973; Russett 1990; Chan 1997; Saideman 2001). The democratic peace (or liberal peace) argument suggests there is a direct link between states' domestic and international behaviors. This theory maintains that no democratic pair of states has fought each other since the early nineteenth century. Russett (1990), Chan (1997), Doyle (1986), and Maoz and Russett (1992) have presented statistical evidence for this argument and underpinned the so-called cultural and institutional explanations of liberal peace. The institutional explanation suggests peace between democracies is due to institutional rules that limit use of force by the government (Bueno de Mesquita, Morrow, Siverson and Smith 1999 and Bueno de Mesquita, Koch and Siverson 2004). The cultural 
explanation of democratic peace posits that democracies develop a political culture where settling disputes by peaceful means becomes a norm that prevents democracies from fighting each other (Maoz and Russett 1993). In other words, regime type directly affects how countries behave internationally.

The third literature related to our study analyzes whether a domestic environment of inequality influences states' international use of violence (Doyle 1986; Harrington 1992; Weart 1994; Rummel 1997; Caprioli 2000; Caprioli and Boyer 2001; Sobek, Abouharb and Ingram 2006; Fox and Sandal 2010; Peterson and Graham 2011). More specifically, some researchers have argued that "a domestic environment of inequality and violence results in a greater likelihood of state use of violence internationally" (Caprioli and Trumbore 2003a:6). The logic in most of these studies is similar: "a society that arbitrarily discriminates against some of its citizens" will be more likely to "exhibit violence in their foreign policy as they externalize a world-view centered on their own sense of superiority" (Caprioli and Trumbore 2003a:7).

Connections between unjust treatment of identity groups in a state and that state's international behavior are explored in depth by the ethnic politics and feminist scholarships (Caprioli and Trumbore 2003a,b). The ethnic politics literature suggests ethnic discrimination to be an important trigger of ethnic dissent (Jenne, Saideman and Lowe 2007), which can develop into interstate conflict (Gurr 1993; Gurr and Harff 1994). ${ }^{3}$ Feminist scholarship focusing on domestic gender discrimination and foreign policy linkages proposes that violence at different levels of society is not independent from each other (Tickner 2001). ${ }^{4}$ Tickner (1992) suggests that all hierarchical patterns of domination and subordination may be based on gender, class, race, religion, or ethnicity and are ever present across the international system, thus challenging the maintenance of international peace and order. Caprioli and Trumbore (2003a:5) confirm that states characterized by higher levels of ethnic discrimination are more likely to exhibit higher levels of hostility or use force in international disputes. Carment and James (1997) and Carment, James and Taydas (2006) suggest that ethnopolitical conflict is the main variable between domestic discrimination of minority groups and violence toward a state with a majority population of the same ethnic group. Also, albeit a contested term, the rogue states described as those that violate human rights norms of gender and ethnic nondiscrimination and protection from state repression are more likely to engage in aggressive interstate behavior (Caprioli and Trumbore 2003b and Caprioli and Trumbore 2006; Hudson, Caprioli, Ballif-Spanvil, McDermot and Emmett 2008/09; Mitchell and Trumbore 2012) and violate international regulations around weapons of mass destruction (WMD), and sponsor terrorism (Caprioli and Trumbore 2007). Research studying how domestic behavior affects international behavior from different perspectives has reached similar conclusions. For example, Sobek et al. (2006) claimed that states that respect human rights domestically are more likely to have relatively peaceful relations. Peterson and Graham's (2011) research shows conflict initiation is more likely when states have disparate levels of respect for physical integrity rights.

Some studies have attempted to go beyond case-supported theoretical arguments and have tested whether the host-rival state pairwise conflict can be statistically accounted for by domestic discrimination of the minority in question. Davis, Jaggers and Moore (1997)and Moore and Davis (1998) hypothesized that high levels of discrimination against a domestic ethnicity will cause more conflict

\footnotetext{
${ }^{3}$ For more on ethnic discrimination and state behavior at the international level, see Carment 1993; Kupchan 1995 and Van Evera 1997.

${ }^{4}$ For more on gender inequality and hierarchical social structures, see Bunch and Carrillo 1998 and Humm 1990.
} 
between the discriminatory state and a rival state governed by the ethnic brethren of the discriminated group. Although neither study found significant support for this argument, Caprioli and Trumbore (2003a) suggested that both studies suffered significantly from data and theoretical problems and that more advanced analyses have found support for the hypothesis in question.

Our study, on the other hand, does not focus on pairwise conflict relations between a discriminated group's state and the same group's international allies; we are interested in whether a state that engages in discriminatory behavior against its ethnoreligious minorities is more likely to initiate and engage in foreign policy crises in general; not the probability of discriminatory state's initiating or becoming involved in a crisis with a state due to ethnic or religious affinity with the discriminated minority. Drawing upon the growing body of literature that suggests a theoretical and empirical link between a domestic environment of inequality for a state's ethnic groups and that state's foreign policy, this study argues that foreign policy patterns regarding involvement in international crises may be partially explained through a state's unjust treatment of its ethnoreligious groups. We propose that if a state discriminating domestically is more likely to engage in use of force abroad, as the literature suggests, those states should experience more international problems with various actors and be more likely to initiate and become involved in international crises.

\section{Religion in Foreign Policy and Religious Discrimination}

Our main reason for analyzing the effects of a specific variable such as religious discrimination is that religious affinities seem to be regaining their traditional influence over foreign policy decisions. Studies in the field of American foreign policy suggest religious identities shape citizens' electoral choices (such as in the 2004 presidential election (Guth, Kellstedt, Smidt and Green 2006); that they have become more important in foreign policy making in the United States after 9/11 (Miles 2004); and that religious congregations have a direct impact on voters' opinion on foreign policy issues (Wuthnow and Lewis 2008). Similarly, Haynes (2008) explains how "religious soft power" by Evangelical groups influences US foreign policy.

The literature on identity suggests religion is a highly salient component of individual and collective identity, shaping believers' perceptions and worldviews and providing answers to questions about human origins (Seul 1999; Voye 1999; Kinvall 2004; Lai 2006; Warner and Walker 2011). Religious values are influential because they carry a philosophy of life or moral values that can shape people's beliefs about their "place in the world and the manner in which the world is meaningfully put together" (Fox 2004b:58). When religion is an integral part of interaction among groups, it "helps to construct both the individual's and the group's value system and world-view" (Abu-Nimer 2001:687-688) and creates a bond of unity among its adherents. When religious values collide, religious identity becomes a source of conflict because people consider themselves in a zerosum game where their whole moral framework is in danger. Therefore, religion is frequently cited as a source of international (Henderson 1997) and ethnic conflict (Fox 2004a) and has become an important area of foreign policy inquiry for political scientists.

Religious discrimination as a source of social and international conflict essentially prevents group members from performing simple yet salient acts of religious practice, such as observing religious services and festivals, accessing places of worship, and wearing religious symbols or clothing. Members of a religious minority perceive discriminatory policies as fundamental threats to their moral framework and develop antagonistic feelings toward the perpetra- 
tors of such policies. Acts of discrimination by government are perceived by the victims as evidence of the government's intolerance and lack of respect for other belief systems. A religious minority facing discrimination will seek to stop the restrictions, including pursuing external political and material support (Gurr 2000). Domestic repression of religious minorities may thus result in problems with other states, especially with states that share the same religious background as the repressed minority. A state's level of religious discrimination against an ethnoreligious group also reflects its level of (in)tolerance, repression, and (in)equality. As the aforementioned discussion suggests, a country that discriminates at home may have a sense of superiority, which can cause international problems and crises. Based on previous research on ethnic inequality, a state may duplicate its discriminatory domestic policy pattern at an international level, resulting in a crisis. Such features are instrumental in explaining how religious affinity combined with religious discrimination can influence foreign policy decisions.

The salience of religion as one of the sources of ethnic identity is illustrated in various examples in world politics, such as the continuing Kashmir conflict, which started with the partition of India and Pakistan in 1947. Identification of an ethnic group is determined by common perceptions among its members, and conflict between these groups carries an ethnic quality to it. If there is a primary religious difference among the parties, the ethnic conflict can assume a religious dimension. Armed conflict between the Indian government and Muslim groups in Kashmir has induced support for the Muslims from neighboring Pakistan, a country with a predominantly Muslim population. Such support has resulted in India's foreign policy reactions and nuclear rivalry between the two neighbors. Events such as the destruction of the Babri Mosque in Ayodhya on December 6, 1992, and the communal riots in Gujarat in 2002 that claimed at least 1,000 lives help Pakistan justify its continued involvement in India's domestic policies.

Factor theory, explained in the next section, aims to account for such complex linkages between domestic discrimination and foreign policy crises. When one further explores India's relations with its minorities, we observe that it also maintains problematic relations with other countries, such as China, Sri Lanka, Nepal, and Bangladesh. India has either initiated or been involved in international crises since its independence in 1945. As we argue in this paper, governments that systematically discriminate against domestic religious minorities may be more inclined to maintain conflictual IR, which may lead to increased involvement in international crises.

Based on the discussion above, we expect that higher levels of religious discrimination in a state will increase the likelihood that it will initiate or become involved in an international crisis. The expected relationship between religious discrimination and foreign policy crisis initiation and crisis proneness can be expressed in the following testable hypotheses:

Hypothesis 1: The higher the level of religious discrimination against ethnoreligious minorities in a country, the higher the likelihood that country will initiate an interstate crisis.

Hypothesis 2: The higher the level of religious discrimination against ethnoreligious minorities in a country, the higher the likelihood that country will become involved in an interstate crisis.

After building religious discrimination and foreign policy crisis linkages, this study turns to FPA studies that have focused on such relationships and builds a 
theoretical model to demonstrate how domestic ethnoreligious problems affect states' foreign policies.

\section{Foreign Policy Model}

Our foreign policy approach is adapted from McGowan and Shapiro's classic 1973 work on comparative foreign policy studies, which synthesized insights from the FPA literature and suggested a general framework for analysis. We use this approach because the choice of factors fits well with the nature of foreign policy studies; that is, the external and subnational components employed give a comprehensive picture, introducing an interdisciplinary understanding of history, religion, economics, sociology, anthropology, psychology, and political science. The factor model provides theoretical justification for building connections between domestic religious discrimination and foreign policy crises and guides statistical testing of these relationships. McGowan and Shapiro (1973:40-51) survey the variables in the literature that appear to be the most important for explaining foreign policy patterns and organize them in a loose theoretical manner. The authors suggest this framework is not fit for theory testing but should instead be used as a base to integrate "factor theories" of foreign policy behavior (p. 49). ${ }^{5}$ We accept this challenge and present a factor theory that uses the original framework's insights and then add a further domestic dimension. Our theory is more parsimonious, including fewer factors (or variables) that may have a direct influence on foreign policy behavior with domestic ethnoreligious causes. Our choice of independent variables parallels the findings from the FPA and ethnoreligious conflict literatures.

Figure 1 shows the structure of our factor theory of religious discrimination and foreign policy behavior. The main independent variable is the level of religious discrimination against an ethnoreligious minority in a given country. The dependent variables are interstate crisis initiation (triggering entity) and interstate crisis involvement, as defined in the International Crisis Behavior (ICB) data set. ${ }^{6}$ The direction of the relation is positive, that is, the more religious discrimination against ethnoreligious groups in a country, the more likely that country will initiate or engage in a foreign policy crisis.

We derive the control variables from McGowan and Shapiro's survey and other relevant literature. The variables are, categorically, other nations' policies (for example, threats, threats of use of force, use of force, sanctions), systemic factors (for example, relevant characteristics of the international system, neighbors, regional variables, alliances, international organization (IO) membership), and domestic control variables, such as political (for example, the regime, system, political discrimination in a country), governmental (for example, capabilities, bureaucracy, military), economic (for example, economic discrimination, type of economic system, level of economic development), and cultural-contextual (for example, nationalism, religious movements, media).

\footnotetext{
${ }^{5}$ McGowan and Shapiro's framework has been used in other studies to build factor theories that aim to explain the origins of domestic-level ethnic and religious factors that experience internationalization. For example, James and Özdamar $(2005,2008)$ developed a model in line with more recent developments in the FPA literature and applied the novel framework to two ethnicity- and religion-based foreign policy cases: Turkish-Syrian relations over the PKK (Kurdistan Workers' Party; an armed separatist Kurdish terrorist organization) and Indo-Pak relations over the Kashmir conflict.

${ }^{6}$ To be considered a foreign policy crisis, a situation must have the following three sufficient conditions, which derive from change in a state's external or internal environment: "a threat to one or more basic values,... finite time for response,... a heightened probabaility of involvement in...military hostilities” (Brecher and Wilkenfeld 2000: 3). A foreign policy crisis situation is the appropriate choice for the foreign policy framework in this study because it captures the heightened probability of involvement in military hostilities, rather than just involvement in military hostility.
} 
Input Variables

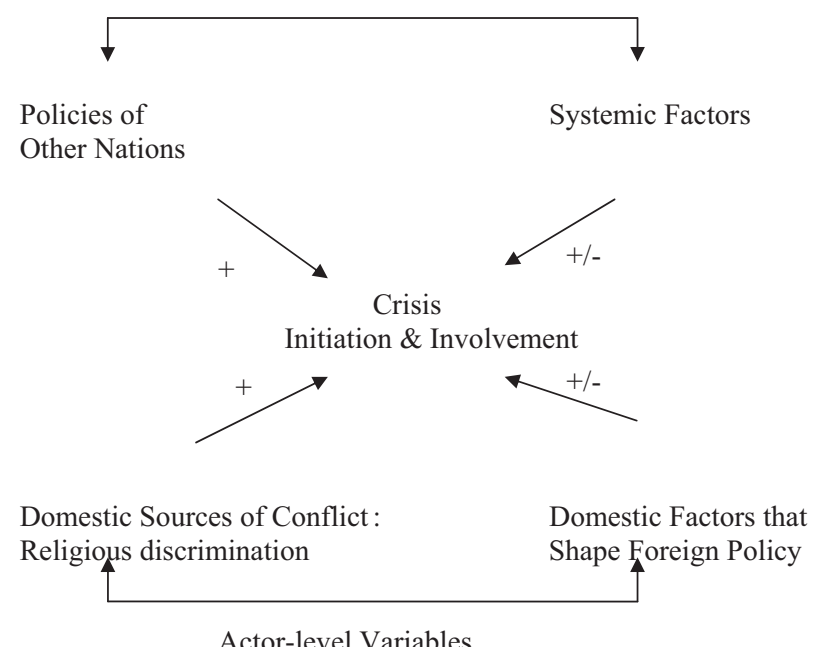

Actor-level Variables

FIG 1. Structure of a Factor Theory of Religious Discrimination and Foreign Policy Crisis

In this theoretical framework, a domestic issue (religious discrimination against ethnoreligious groups in a given state) is the original source of the conflict. This conflict attracts other states' interest for reasons ranging from purely humanitarian motivations to real politik to weaken the host state. The more "meddling" there is from another nation, the higher the likelihood of crisis occurrence and the country becoming a crisis initiator. ${ }^{7}$ Threats and sanctions from an adversary are the two important variables that specifically relate to our study. In addition, systemic factors, such as a state's capabilities, as measured by the Composite Index of National Capability (CINC), have a direct influence on foreign policy behavior.

Systemic pressures and other nations' policies are input variables in the original McGowan and Shapiro (1973:41) model. These inputs are processed at the domestic level and produce outputs that become foreign policy patterns. From a wide range of domestic variables, we chose a handful deemed important in the ethnoreligious discrimination-foreign policy linkages literature, reflecting McGowan and Shapiro's suggestion regarding building specific factor theories. ${ }^{8}$ Our variables reflect political, governmental, economic, and cultural characteristics of the minority's host country, such as regime type (democracy vs autocracy) and a country's general capabilities. Gross domestic product and whether the government economically discriminates against minorities are relevant economic variables, and as a cultural factor, we measure level of nationalism because it appears to be significant in accounting for foreign policy behavior against adversaries.

As in the original, our model strives for operational consistency when applied to comparative foreign policy. It seeks to coordinate existing approaches to create a more parsimonious framework to explain domestic policies-international behavior linkages. If successful, the model will be able to incorporate the wide range of literature on foreign policy; statistical testing of the model against large-N data sets will evaluate its explanatory power.

\footnotetext{
${ }^{7}$ Meddling by a country governed by a host country's ethnic brethren is only one reason for a state to be involved in a crisis; therefore, one of the two dependent variables we use is general crisis involvement rather than specifically a crisis with a state that contains the same ethnoreligious group.

${ }^{8}$ McGowan and Shapiro's original variables were as follows: individual, elite, politics, government, economics, linkages, analogies, culture, establishment, and society.
} 


\section{Research Design and Measurement}

We conduct a statistical analysis to empirically test whether states characterized by high religious discrimination against ethnoreligious groups are more likely to initiate or become involved in international crises. We find a large- $\mathrm{N}$, time-series cross-section data to be an appropriate choice as it allows for evaluating the model across a large number of cases over a time span. Due to data limitations, the quantitative analysis spans the 1990-2003 time period for Model 1 and the 1990-2001 time period for Model 2. ${ }^{9}$ We drop CINC as a domestic control variable in the first model to add a temporal domain to the study. The unit of analysis is the country for a given year. ${ }^{10}$ We use a logistic regression estimator on all models. All independent and control variables are lagged for 1 year. Dependent, independent, and control variables are described in detail in the following section.

The data for this project came from several data sets: ICB, Integrated Data for Event Analysis (IDEA), Polity IV Project, Correlates of War (COW) Project (National Material Capabilities Dataset), United Nations' statistical database, Database of Political Institutions (2009), Minorities at Risk (MAR), and independent data collection on religious discrimination.

\section{Dependent and Independent Variables}

\section{Dependent Variables: International Crisis Initiation (Triggering Entity) and International Crisis Involvement \\ International Crisis Initiation (Triggering Entity)}

Using ICB's "triggering entity" variable, we determined whether a country triggered a foreign policy crisis in a given year. We coded this variable as a dummy variable, where " 1 " connotes at least one crisis initiation by the country in a given year and " 0 " no crisis initiation in a given year. To clarify the coding procedure, if for a given year no international crises are initiated by a particular country, the country is coded to have a 0 value of crisis initiation for that year. We use crisis initiation as one of the dependent variables of our study, with the focus to test whether discriminatory states are more likely to initiate foreign policy crises.

\section{International Crisis Involvement}

Using the listed cases of crises, we created a crisis variable that identifies whether the country had a crisis in a given year. We coded this variable as a dummy variable where " 1 " connotes crisis and " 0 " otherwise. To clarify the coding procedure, if for a given year no international crises are noted by the ICB for a specific country, the country is coded to have a 0 value of crisis for that year. We use crisis occurrence as one of the dependent variables of this study, with the focus to test whether discriminatory states are more likely to become involved in foreign policy crises.

\section{Independent Variable: Religious Discrimination}

The variable at the bottom left of the model in Figure 1 (that is, domestic sources of ethnoreligious conflict) is covered by original data coded on religious discrimination, which is a composite measure of the degree of discrimination against an ethnoreligious minority in any given state. It is defined as the extent to which state behavior restricts the religious practices of ethnoreligious minori-

\footnotetext{
${ }^{9}$ As this study examines a limited temporal domain, any finding stated must be considered for the specific time frames listed.

${ }^{10}$ Only countries with an ethnoreligious minority at risk (MAR) are added to the analysis.
} 
ties compared to members of the majority religion. This study employs an independently collected religious discrimination index composed of 24 aspects (variables) of religious discrimination against ethnoreligious minorities-at-risk coded annually for the period 1990-2004. We formed an index of religious discrimination by summing up the 24 variables and measuring the overall degree of religious discrimination toward ethnoreligious minorities in any given state. ${ }^{11}$ The index provides a robust proxy of religious grievances and is a highly valid indicator of religious discrimination, as it includes a broad range of discriminatory state acts and policies. To the best of our knowledge, this variable is the broadest and most comprehensive religious discrimination indicator available at the MAR level. ${ }^{12}$ Values of this index range from 0 to 48 . If a country has more than one ethnoreligious MAR, the maximum value of religious discrimination is coded for country year.

Each of the 24 variables, which range from 0 to $2(0=$ no discrimination, $1=$ low discrimination, $2=$ high discrimination), aims to capture a different aspect of state restriction on minority religion. If a variable is coded 0 , this means the sources included no information on the existence of a specific religious restriction. For example, "forced observance of religious laws of another group" is one of the 24 variables. If that variable is coded as 0 for the minority in a given year, it means that particular minority faced no pressure to follow the religious laws of another group. If the variable is coded as 1 , a slight restriction was in effect. The restriction could mean different things; for instance, it may suggest pressures to observe the laws of another religion only in government offices. If the variable is coded 2, it means all or almost all members of the ethnoreligious group were forced to observe the religious laws of another group.

All 24 aspects of religious discrimination were coded using various sources, including MAR reports, Religion and State (RAS) data set country reports, annual reports to Congress on international religious freedom, and Human Rights without Frontiers' annual news. ${ }^{13}$ Some of the other variables are restrictions on publicly observing religious services, on building, repairing, and/or maintaining places of worship, and on wearing religious symbols or clothing. The complete list of variables used to create the composite indicator can be found in Appendix 1.

\footnotetext{
${ }^{11}$ Cronbach's alpha coefficients with both raw and standardized variables for each year are all greater than or equal to 0.91 .

${ }^{12}$ The Fox (2000) religious discrimination index is at the MAR level, yet it includes only eight indicators. The Religion and State (RAS) data set is a comprehensive data set on the intersection between government and religion (Fox 2008). To learn more about studies that have used this data set, see http://www.thearda.com/ras/publications/ (accessed on August 20, 2012). Restrictions on minority religions are available from the RAS data set. Religious discrimination indicators of the RAS data set are accounted for in our data collection. We also used the RAS country reports, available directly from RAS project director Jonathan Fox. Note that the religious discrimination variable in the RAS data set is at the state level (RAS codebook: 5). The RAS-Minorities data set, a specialized version of the RAS data set, is at the religious minority level; however, it does not account for ethnoreligious minorities, that is, ethnic minorities with a different religious identity than the majority of the population. The data set in our study accounts for religious discrimination variables in the RAS data set, but we collected data at the ethnoreligious minority level.

${ }^{13}$ MAR reports are available in the qualitative analysis section of the MAR webpage at http://www.cidcm.umd. edu/inscr/mar/data.asp. Annual reports to Congress on international religious freedom are available on line at http://www.state.gov/g/drl/irf/rpt/. These reports describe the status of religious freedom in each country and describe government policies that violate the religious practices of groups, denominations, and individuals. http:// www.hrwf.net/ is the home page of Human Rights without Frontiers. Annual news catalogues and reports on special issues and projects are available from this site.
} 


\section{Control Variables}

Control variables reflect extant country conditions that the factor theory argues should account for international crises. The other nations' policies variable is operationalized with two variables from IDEA: threats/coercive warnings and sanctions (Bond et al. 2003). In terms of systemic factors, the most obvious one (power distribution at the systemic level) is a constant for this period because we deal with the post-Cold War era. We added region and number of neighbors to the analysis as other systemic factors. Domestic control variables that influence foreign policy making are incorporated using regime type, economy, and CINC variables. Because we deal with the question of religious discrimination's effects on foreign policy, other significant types of discrimination such as political and economic must also be controlled for, and the MAR data set considers these factors. To control for relevant cultural factors, we added a variable (Beck, Clarke, Groff, Keefer, and Walsh 2001) that measures whether the chief executive party of a country is nationalist to the analysis to measure the level of nationalism in a country. More information on the variables and data sources used is found below.

\section{Political and Economic Discrimination}

Political and economic discrimination against ethnic minorities is controlled for by using the discrimination data set of the MAR project. This data collection "records overall levels of political and economic discrimination for all groups in the Minorities at Risk Project for the period 1950-2003." ${ }^{14}$ Both variables range from 0 to 4 ( $0=$ no discrimination; $1=$ neglect $/$ remedial policies; 2 = neglect $/$ no remedial policies; $3=$ social exclusion/neutral policy; $4=$ exclusion $/$ repressive policy). If a country has more than one minority, we considered the values of the minority most discriminated against in the analysis.

\section{Regime Type}

The regime characteristics of a country are controlled for by using the revised combined polity score (polity2) from the Polity IV data set. This variable is a modified version of the combined annual polity score. It still involves the 21point index created by subtracting the autocracy from the democracy scores $(-10-10)$; the main difference is that standardized authority scores (that is, -66 , -77 , and -88 ) are converted to conventional polity scores (that is, values within the range $-10-+10)$, which facilitates the use of the polity regime measure in time-series analyses (Polity IV codebook). Regime type is an important factor in terms of the emergence or degree of religious discrimination, how the problem is handled by central governments that influence other states' policies, and in terms of a foreign policy crisis.

\section{Composite Index of National Capability}

A country's national capabilities are assumed to influence its foreign policy behavior and its relations with other actors in the international system. Therefore, the CINC score from the COW, national capability data set, version 3.02, is used to account for a state's overall capability in a given year. ${ }^{15}$

\footnotetext{
${ }^{14}$ http://www.cidcm.umd.edu/mar/data.asp (Accessed on August 20, 2012); the MAR codebook explaining the measurement of both variables can be found on this page as well.

15 The CINC score is calculated in the following way: six components (iron and steel production, military expenditures, military personnel, energy consumption, total population, and urban population) are summed up for a given year, converting each state's absolute component into a share of the international system. The CINC value is then calculated by averaging across the six components.
} 


\section{Threat and Sanction Variables}

We used the following IDEA variables to capture the policies of other nations: threats/coercive warnings (not otherwise specified) and sanctions (not otherwise specified). We included threats and sanctions in the analysis only if the event had a different trigger and target state. Since the unit of analysis is a country in a given year, we added cases that targeted that state in a specific year. In cases where there was more than one sanction and threat to a country, we added the number of events. For example, if a country was the target of three different sanctions in 2000, the sanction value for 2000 for that country is 3 . Threat and sanction variables are an integral part of the model because the causal linkages made between a domestic religious problem and another state's involvement in it may result in a foreign policy crisis.

\section{Number of Neighbors}

We used the number of border countries (from Nation Master) to capture systemic concerns. ${ }^{16}$ We chose this factor as a control variable because in McGowan and Shapiro's original study, such systemic and subsystemic characteristics have a direct impact on a state's foreign policy and crisis involvement. More neighbors mean an increased likelihood of involvement in crises and war, ceteris paribus.

\section{Region}

Similarly, in the original McGowan and Shapiro model, the region in which a country is located has an impact on its foreign relations. Some regions, such as the Middle East, appear to be more prone to inter- and intrastate conflict, while South America, for example, has almost never experienced interstate armed conflicts. We used the MAR data set's region variable in this test, which simply identifies a country's geographic region.

\section{Per Capita GDP}

We extracted per capita GDP values at current prices in US dollars from the United Nations' statistical database. ${ }^{17}$ We chose per capita GDP as a control variable because the literature suggests a positive relationship between economic development and becoming involved in a foreign policy crisis.

\section{Chief Executive Party: Nationalist}

This variable is derived from the Database of Political Institutions $(2009)^{18}$ and determines whether in a given year the chief executive party of a country is nationalist. It is a dummy variable, where " 1 " connotes the chief executive party to be nationalist and " 0 " otherwise.

\section{Splines}

To control for autocorrelation, we fitted cubic splines. We created cubic B-spline bases using two equally spaced knots using year variable in the data set.

\footnotetext{
${ }^{16}$ http://www.nationmaster.com/red/graph/geo_lan_bou_bor_cou-geography-land-boundaries-border-countries\&int=-1 (Accessed on January 29, 2010). As only the most recent data for the number of bordering countries were available, the value is constant for each country for the time frame analyzed.

${ }^{17}$ http://data.un.org/Data.aspx?q=GDP\&d=SNAAMA\&f=grID:101;currID:USD;pcFlag:1 (Accessed on January $24,2010)$. When GDP was included in the analysis, beta values were very small. To overcome this, we divided GDP values by 1000 .

18 http://econ.worldbank.org/WBSITE/EXTERNAL/EXTDEC/EXTRESEARCH/0,,contentMDK:20649465 pagePK:642 14825 piPK:64214943 theSitePK:469382,00.html (Accessed June 28, 2010).
} 
TABLE 1. Logistic Analysis of Crisis Initiation (DV: Triggering Entity)

\begin{tabular}{lcr}
\hline Independent Variable & Model 1 & Model 2 \\
\hline Religious Discrimination & $0.074(0.027)^{* * *}$ & $0.090(0.030)^{* *}$ \\
Political Discrimination & $-0.357(0.176)^{*}$ & $-0.162(0.212)$ \\
Economic Discrimination & $0.188(0.191)$ & $-0.081(0.235)$ \\
Regime Type & $0.013(0.036)$ & $0.026(0.039)$ \\
CINC Score & - & $26.702(6.972)^{* * *}$ \\
GDP & $0.056(0.026)^{*}$ & $0.016(0.036)$ \\
Threat & $0.277(0.631)$ & $-0.279(0.821)$ \\
Sanction & $0.096(0.106)$ & $0.036(0.129)$ \\
Number of Neighbors & $0.038(0.072)$ & $-0.111(0.093)$ \\
Region & $0.091(0.110)$ & $0.211(0.132)$ \\
Nationalist Executive Party & $0.747(0.515)$ & $0.983(0.543)$ \\
Spline 1 & $0.465(1.094)$ & $1.572(1.263)$ \\
Spline 2 & $-0.480(0.833)$ & $-1.180(1.066)$ \\
Spline 3 & $-0.642(1.297)$ & $4.529(2.966)$ \\
Constant & $-4.432(0.960)^{* * *}$ & $-4.980(1.105) * * *$ \\
-2 Log-likelihood & 250.996 & 209.158 \\
$\chi^{2}$ & 22.359 & 41.018 \\
$N$ & 859 & 729 \\
\hline
\end{tabular}

(Notes. Standard errors are in parentheses. Percentage correctly predicted for model vs modal category: Model 1 percentages 91.9/40.6; Model 2 percentages $91.4 / 46.7 . * p<.05 ; * *<.01 ; * * p<.001)$.

\section{Data Analysis, Results, and Discussion}

We present our results in Tables 1 and Table 2. ${ }^{19}$ Model 1 examines the 1990 -2003 time frame, and Model 2 analyzes the 1990-2001 time period (the CINC variable is available only until 2001). In all the models, the coefficient of religious discrimination is in the expected direction and statistically significant, indicating that it is a predictor of international crisis initiation and involvement. These findings provide direct support for the factor theory proposed in this paper. In line with the expected relationship in the factor theory, as the level of religious discrimination against ethnoreligious minorities increases, there is a marked increase in the likelihood of initiating or becoming involved in an international crisis. Further, the significance of the main independent variable is in line with other studies in the field that propose that states engaging in domestic discrimination and violence are likely to face more foreign policy crises and conflicts (Caprioli and Trumbore 2003a). These findings also support the thesis that ethnic discrimination may lead to ethnic dissent, which can eventually turn into interstate conflict (Gurr and Harff 1994).

The CINC variable shows a statistically highly significant and positive relationship with the outcome variables in all the models it is included in. Among the IDEA variables, while threat is not a significant indicator, sanction, with a positive coefficient, is found to be a strong predictor of crisis involvement. In the crisis initiation models, none of the IDEA variables is statistically significant. The number of neighbors variable is not significant in any of the models. GDP is significant only in Model 1 in both tables, with a positive coefficient. While political discrimination is significant in two models, with a negative coefficient, economic

\footnotetext{
19 The model is very good at ranking probabilities; however, since the distribution is skewed (crisis initiation and involvement are rare events), the predictions are skewed toward 0. Modifying the classification cutoff point (to 0.08 for all models) was sufficient to deal with this problem. For crisis initiation, we began with 0.04 and through trial and error moved to 0.08 . For crisis involvement, we began with 0.18 and through trial and error moved to 0.08 .
} 
TABLE 2. Logistic Analysis of International Crisis (DV Crisis Involvement)

\begin{tabular}{lcr}
\hline Independent Variable & Model 1 & Model 2 \\
\hline Religious Discrimination & $0.055(0.021)^{*}$ & $0.058(0.023)^{*}$ \\
Political Discrimination & $-0.395(0.122)^{* *}$ & $-0.254(0.143)$ \\
Economic Discrimination & $0.303(0.136)^{*}$ & $0.132(0.160)$ \\
Regime Type & $-0.015(0.026)$ & $-0.018(0.028)$ \\
CINC Score & - & $18.909(5.123)^{* * *}$ \\
GDP & $0.062(0.018)^{* *}$ & $0.037(0.023)$ \\
Threat & $-0.334(0.645)$ & $-0.974(0.879)$ \\
Sanction & $0.310(0.110)^{* *}$ & $0.359(0.126)^{* *}$ \\
Number of Neighbors & $0.003(0.053)$ & $-0.123(0.064)$ \\
Region & $-0.003(0.082)$ & $0.064(0.094)$ \\
Nationalist Executive Party & $0.433(0.413)$ & $0.450(0.445)$ \\
Spline 1 & $-0.888(0.844)$ & $-0.457(0.945)$ \\
Spline 2 & $0.494(0.596)$ & $0.505(0.746)$ \\
Spline 3 & $-1.186(0.905)$ & $-0.015(2.173)$ \\
Constant & $-2.992(0.696)^{* * *}$ & $-2.996(0.768)^{* * *}$ \\
-2 Log-likelihood & 402.334 & 332.686 \\
$\chi^{2}$ & 53.176 & 62.326 \\
$N$ & 859 & 729 \\
\hline
\end{tabular}

(Notes. Standard errors are in parentheses. Percentage correctly predicted for model vs modal category: Model 1 percentages 74.0/62.5; Model 2 percentages 80.5/66.1. $\left.{ }^{*} p<.05 ; * * p .01 ; * * p<.001\right)$.

discrimination is significant in one model, with a positive coefficient. The key internal indicator, that is, religious discrimination, in the proposed theory of religious discrimination and foreign policy crises, is found to be significant in all models. $^{20}$

In general, the results show a great deal of support for the explanatory power of our factor theory. ${ }^{21}$ First, the primary linkage hypothesized in the theory section, that is, a positive relation between religious discrimination at the domestic level and initiating and becoming involved in foreign policy crises, is supported by evidence in all statistical tests. The sanction variable also appears to be in line with the expectations in the two models. Provoking foreign policy interaction increases the likelihood of engaging in a crisis. The CINC score is also statistically significant. Perhaps the most interesting result of the test is the regime type variable: The model hypothesizes that democracies are more able to resolve ethnoreligious conflict issues, which eventually would decrease the likelihood of becoming involved in a foreign policy crisis or initiating one. The test, however, does not support this premise. It appears to support the studies that suggest regime type is not a good predictor of foreign policy behavior. Finally, the region variable also did not appear to be statistically significant. In further studies of the factor model, perhaps these results will show that new variables capable of measuring systemic effects need to be used.

\footnotetext{
${ }^{20}$ We also ran Model 2 for both dependent variables without the GDP control. The religious discrimination variable stayed significant with a positive coefficient. For crisis initiation, the following control was significant: CINC score (positive coefficient). For crisis involvement, the following controls were significant: CINC score (positive coefficient), sanction (positive coefficient), number of neighbors (negative coefficient).

${ }^{21}$ Bivariate correlations between the independent variables reveal a maximum of 0.579 (absolute value) for political discrimination and economic discrimination, with most correlations much lower. The VIF scores for independent variables (excluding splines) range from 1.08 to 1.811 . Thus, the results reported are unlikely to be affected by multicollinearity.
} 


\section{Conclusions}

Contrary to the claims of modernization and secularization theorists, culture and religion are important factors in IR (Fox 2004b; Ellingsen 2005). Religious dynamics are the products of historical legacies; they shape governmental and political structures, affect other nations' policies, shape leaders and a society's elite, and help us understand the cultural side of the foreign policy coin. In the developing world, especially, where the exercise of power is often legitimized on religious grounds, the masses can be mobilized through communal consciousness, and power structures can be built on ethnic and religious foundations, thus strengthening explanations about domestic politics and foreign policy.

In an attempt to contribute to the discussion of religion in foreign policy analysis, this paper examined the question of whether religious discrimination exerts an independent effect on international crisis. The foreign policy approach presented here provides further understanding of the relationship between domestic factors and foreign policy. Empirical testing of the model indicates religious discrimination is linked to international crisis. The results also show that the factor theory and the proposed foreign policy model hold their explanatory power in empirical analysis. Recent scholarship on religion in IR has established important links between different dimensions of religion and conflict. As part of the larger research agenda on the empirical analysis of religion in IR, the results provide support for the existing literature that religious discrimination has an impact on the likelihood of initiation of and involvement in international crisis, supporting the idea that religion-related factors may be linked to issues such as violence, civil strife, international crisis, and terrorism.

Our results also show that religious discrimination against ethnoreligious groups is of concern not only because such discrimination violates human rights, but also because countries that practice an unjust environment internally are more prone to crises externally. Furthermore, this study presents insights on a recent debate in IR that systemic variables alone cannot fully explain interstate behavior. Structural theories' parsimony and elegance are achieved at the expense of key domestic variables that directly affect interstate relations. Foreign policy analysis, as the "ground of IR" (Hudson 2005), aims to fill this gap. This study contributes to this aim; specifically, it provides results from a rarely explored field. Studies that focus on the effect of religion on specific foreign policy outcomes are new; bringing an original religious discrimination factor into foreign policy studies is a novel task. The significant results show support for this burgeoning literature and contribute to the accumulation of knowledge in this field.

From the IR theory perspective, this study supports the notion that classic theories fall short of accounting for fuzzy borders between nation-states and global society, between domestic politics and interstate conflicts, between domestic minorities and international influences, and so on. As new tests are conducted, IR theories that focus solely on systemic factors will need to revise their hypotheses about interstate relations. For example, we have observed an interesting pluralist-solidarist, or justice vs. order, debate within the English School literature in the past decades. Our study, by showing domestic-level injustices' influence on interstate behavior, may contribute to this debate. The results support that unjust treatment of domestic minorities is not necessarily only a domestic problem; such policies may serve as warnings of foreign policy behavior that may result in international crises and threaten the "order" of the international system. We suggest that justice vs order, as mutually exclusive categories, do not reflect the whole picture; injustice at home can cause disorder abroad. There- 
fore, the integrated nature of justice and order within the international system should be better emphasized.

For policymakers, these results send a clear message that protecting minorities and preventing ethnoreligious discrimination can decrease and/or prevent interstate crises and conflicts. Mechanisms to monitor, detect, and prevent discriminatory policies should be developed and implemented. International organizations' and NGOs' involvement in this process will help achieve this goal.

Findings supporting our factor model and the effect of ethnoreligious discrimination on interstate crises are promising, yet inconclusive. More thorough examinations of the link between religious identity and states' international behavior should be an important aspect of future research. Our model can be developed in ways to include more specific variables based on the findings of other FPA and ethnicity studies. Religious discrimination's effects on other policy outcomes should also be included in future research agendas.

\section{References}

Abu-Nimer, Mohammed. (2001) Conflict Resolution, Culture, and Religion: Toward a Training Model of Interreligious Peacebuilding. Journal of Peace Research 38 (6): 685-704.

Allison, Graham T. (1969) Conceptual Models and the Cuban Missile Crisis. American Political Science Review 63: 689-718.

Beck, Thorsten, George Clarke, Alberto Groff, Philip Keefer, and Patrick Walsh. (2001) New Tools in Comparative Political Economy: The Database of Political Institutions. World Bank Economic Review 15 (1): 165-176.

Bond, Doug, Joe Bond, Churl Oh, J. Craig Jenkins, and Charles Lewis Taylor. (2003) Integrated Data for Events Analysis (IDEA): An Event Typology for Automated Events Data Development. Journal of Peace Research 40 (6): 733-745.

Brecher, Michael, and Jonathan Wilkenfeld. (2000) A Study of Crisis. Ann Arbor: University of Michigan Press.

Bueno de Mesquita, Bruce, Michael T. Koch, and Randolph M. Siverson. (2004) Testing Competing Institutional Explanations of the Democratic Peace: The Case of Dispute Duration. Conflict Management and Peace Science 21: 255-267.

Bueno de Mesquita, Bruce, James D. Morrow, Randolph M. Siverson, and Alastair Smith. (1999) An Institutional Explanation of the Democratic Peace. American Political Science Review 93 (4): 791-807.

Bunch, Charlotte, and Roxanna Carrillo. (1998) Global Violence against Women: The Challenge to Human Rights and Development. In World Security, edited by Michael T. Klare, and Yogesh Chandrani. New York: St. Martin's Press.

Caprioli, Mary. (2000) Gendered Conflict. Journal of Peace Research 37 (1): 51-68.

Caprioli, Mary, and Mark A. Boyer. (2001) Gender, Violence, and International Crisis. Journal of Conflict Resolution 45 (4): 503-518.

Caprioli, Mary, and Peter F. Trumbore. (2003a) Ethnic Discrimination and Interstate Violence: Testing the International Impact of Domestic Behavior. Journal of Peace Research 40 (1): 5-23.

Caprioli, Mary, and Peter F. Trumbore. (2003b) Identifying 'Rogue' States and Testing their Interstate Conflict Behavior. European Journal of International Relations 9 (3): 377-406.

Caprioli, Mary, and Peter Trumbore. (2006) Human Rights Disputes in Interstate Disputes. Journal of Peace Research 43 (2): 131-148.

Caprioli, Mary, and Peter Trumbore. (2007) Human Rights Rogues: Aggressive, Dangerous, or Both? In Worst of the Worst: Dealing with Repressive and Rogue Nations. edited by Robert I. Rotberg. Washington, DC: Brookings Institution Press.

Carment, David. (1993) The International Dimensions of Ethnic Conflict: Concepts, Indicators, and Theory. Journal of Peace Research 30 (2): 137-150.

Carment, David, and Patrick James. (1997) Wars in the Midst of Peace: The International Politics of Ethnic Conflict. Pittsburg, PA: University of Pittsburg Press.

Carment, David, Patrick James, and Zeynep Taydas. (2006) Who Intervenes? Ethnic Conflict and Interstate Crisis. Columbus: The Ohio State University Press. 
Chan, Steve. (1997) In Search of Democratic Peace: Problems and Promise. Mershon International Studies Review 41: 59-91.

Davis, David R., Keith Jaggers, and Will H. Moore. (1997) Ethnicity, Minorities and International Conflict. In Wars in the Midst of Peace: The International Politics of Ethnic Conflict. edited by David Carment, and Patrick James. Pittsburgh: University of Pittsburgh Press.

Doyle, Michael. (1986) Liberalism and World Politics. American Political Science Review 80: 1151-1170.

Ellingsen, Tanja. (2005) Toward a Revival of Religion and Religious Clashes. Terrorism and Political Violence 17 (3): 305-332.

Fox, Jonathan. (2000) The Effects of Religious Discrimination on Ethno-Religious Protest and Rebellion. The Journal of Conflict Studies 20 (2): 16-43.

Fox, Jonathan. (2004a) Religion, Civilization and Civil War. Lanham: Lexington Books.

Fox, Jonathan. (2004b) Religion and State Failure: An Examination of the Extent and Magnitude of Religious Conflict from 1950 to 1996. International Political Science Review 25 (1): 55-76.

Fox, Jonathan. (2008) A World Survey of Religion and the State. New York: Cambridge University Press.

Fox, Jonathan, and Nukhet Sandal. (2010) State Religious Exclusivity and International Crises between 1990 and 2002. In Religion, Identity and Global Governance: Ideas, Evidence and Practice. edited by James Patrick. Toronto: University of Toronto Press.

Gurr, Ted. (1993) Why Minorities Rebel: A Global Analysis of Communal Mobilization and Conflict since 1945. International Political Science Review 14 (2): 161-201.

Gurr, Ted R. (2000) Peoples versus States: Minorities at Risk in the New Century. Washington, DC: United States Institute of Peace Press.

Gurr, Ted R., and Barbara Harff. (1994) Ethnic Conflict in World Politics. Boulder: Westview.

Guth, James L., Lyman A. Kellstedt, Corwin E. Smidt, and John C. Green. (2006) Religious Influences in 2004 Presidential Elections. Presidential Quarterly 36 (2): 223-242.

Harrington, Mona. 1992. What Exactly Is Wrong with the Liberal State as an Agent of Change? In Gendered States: Feminist Revisions of International Relations Theory. edited by V. Spike Peterson. Boulder, CO: Lynne Rienner.

Haynes, Jefrrey. (2008) Religion and Foreign Policy Making in the USA, India and Iran: Towards a Research Agenda. Third World Quarterly 29 (1): 143-165.

Henderson, Errol A. (1997) Culture or Contiguity: Ethnic Conflict, the Similarity States, and the Onset of War, 1920-1989. Journal of Conflict Resolution 41 (5): 649-668.

Holsti, K. J.. (1970) National Role Conceptions in the Study of Foreign Policy. International Studies Quarterly 14 (3): 233-309.

Holsti, O., and James Rosenau. (1996) Liberals, Populists, Libertarians, and Conservatives: The Link between Domestic and International Affairs. International Political Science Review 17 (1): 29-54.

Hudson, Valerie M. (2005) Foreign Policy Analysis: Actor-Specific Theory and the Ground of International Relations. Foreign Policy Analysis 1 (1): 1-30.

Hudson, Valerie M., Mary Caprioli, Bonnie Ballif-Spanvil, Rose McDermot, and Chad F. Emmett. (2008/09) The Heart of the Matter: The Security of Women and the Security of States. International Security 33 (3): 7-45.

Humm, Maggie. (1990) The Dictionary of Feminist Theory. Columbus: The Ohio State University Press.

James, Carolyn, and ÖZgür Özdamar. (2005) Religion as a Factor in Ethnic Conflict: Kashmir and Indian Foreign Policy. Terrorism and Political Violence 17: 447-467. Reprinted in Jonathan Fox and Shumel Sandler eds. 2006. Religion in World Conflict. London: Routledge.

James, Carolyn, and Özgür Özdamar. (2008) Modeling Foreign Policy and Ethnic Conflict: Turkey's Policies towards Syria. Foreign Policy Analysis 5: 475-494.

Jenne, Erin K., Stephen M. Saideman, and Will Lowe. (2007) Separatism as a Bargaining Posture: The Role of Leverage in Minority Radicalization. Journal of Peace Research 44 (5): 539-558.

Kinvall, Catarina. (2004) Globalization and Religious Nationalism: Self, Identity, and the Search for Ontological Security. Political Psychology 25: 741-767.

Kupchan, Charles A., ED. (1995) Nationalism and Nationalities in the New Europe. Ithaca: Cornell University Press.

LaI, Brian. (2006) Impact of Regime Type on the Influence of U.S. Foreign Aid. Foreign Policy Analysis 2 (4): 385-404.

Maoz, Zeev, and Bruce Russett. (1992) Alliance, contiguity, wealth, and political stability: Is the lack of conflict among democracies a statistical artifact? International Interactions 17 (3): 245-267.

Maoz, Zeev, and Bruce Russett. (1993) Normative and Structural Causes of Democratic Peace, 19461986. The American Political Science Review 87 (3): 624-638.

McGowan, Patrick J., and Howard B. Shapiro. (1973) The Comparative Study of Foreign Policy: A Survey of Scientific Findings. Beverly Hills, CA: Sage. 
Miles, Jack. (2004) Religion and American Foreign Policy. Survival 46 (1): 23-37.

Mitchell, Sara Mclaughlin, and Peter F. Trumbore. 2012. Rogue States and Territorial Disputes. Presented at the ISA Annual Meeting, San Diego.

Moore, Will., And David R. Davis. (1998). Transnational Ethnic Ties and Foreign Policy. In The International Spread of Ethnic Conflict: Fear, Diffusion and Escalation. edited by David Lake, and Donald Rothchild. Princeton: Princeton University Press.

Peterson, Timothy M., and Leah Graham. (2011) Shared Human Rights Norms and Military Conflict. Journal of Conflict Resolution 55 (2): 248-273.

Rosenau, J. (1966). Pre-Theories and Theories of Foreign Policy. In Approaches to Comparative International Politics. edited by R. Barry Farrell. Evanston, IL: Northwestern University Press.

Rosenau, J. (1987) Roles and Role Scenarios in Foreign Policy. In Role Theory and Foreign Policy Analysis. edited by S. G. Walkerpp. Durham, NC: Duke University Press.

Rummel, R.J.. (1997) Is Collective Violence Correlated with Social Pluralism? Journal of Peace Research 34: $163-175$.

Russett, Bruce. (1990) Controlling the Sword: The Democratic Governance of National Security. Cambridge, MA: Harvard University Press.

Saideman, Stephen M. (2001) The Ties That Divide: Ethnic Politics, Foreign Policy, and International Conflict. New York: Columbia University Press.

Seul, R. Jefrrey. (1999) 'Ours is the Way of God': Religion, Identity, and Intergroup Conflict. Journal of Peace Research 36 (5): 553-569.

Sobek, D., M. R. Abouharb, and C. G. Ingram. (2006) The Human Rights Peace: How the Respect for Human Rights at Home Leads to Peace Abroad. Journal of Politics, 68: 519-529.

Tickner, Ann. (1992) Gender in International Relations: Feminist Perspectives on Achieving Global Security. New York: Columbia University Press.

Tickner, J. Ann.. (2001) Gendering World Politics. New York: Columbia University Press.

Van Evera, Stephen. 1997. Nationalism and War. In Nationalism and Ethnic Conflict. edited by Michael E. Brown, Owen R. Coté Jr, Sean M. Lynn-Jones, and Steven E. Miller. Cambridge, MA: MIT Press.

Voye, Liliane. (1999) Secularization in a Context of Advanced Modernity. Sociology of Religion 60 (3): 275-288.

Warner, C. M., and S. G. Walker. (2011) Thinking About the Role of Religion in Foreign Policy: A Framework for Analysis. Foreign Policy Analysis, 7: 113-135.

Weart, Spencer R. (1994) Peace among Democratic and Oligarchic Republics. Journal of Peace Research 31 (3): 299-316.

Wilkenfeld, Jonathan. (1973) Conflict Behavior and Linkage Politics. New York: McKay.

Wuthnow, Robert, and Valerie Lewis. (2008) Religion and Alturistic U.S. Foreign Policy Goals: Evidence from a National Survey of Church Members. Journal for the Scientific Study of Religion 47 (2): 191-209.

\section{Appendix 1 \\ Religious Discrimination Index ${ }^{22}$}

Coding scale of each variable
$2=$ The activity is prohibited or sharply restricted (high discrimination).
$1=$ The activity is slightly restricted (low discrimination).
$0=$ The activity is not restricted (no discrimination).

Variables coded:

- Restrictions on public observances of religious services, festivals, and/or holidays, including the Sabbath.

- Restrictions on building, leasing, repairing, and/or maintaining places of worship.

- Restrictions on access to places or worship.

- Forced observance of religious laws of another group.

\footnotetext{
${ }^{22} 16$ of these variables are also coded by the Religion and State (RAS) data set at the state level.
} 
- Restrictions on formal religious organizations.

- Restrictions on running religious schools and/or religious education in general.

- Restrictions on the ability to make and/or obtain materials necessary for religious rites, customs, and/or ceremonies.

- Mandatory education in the majority religion (Code as 1 if some but not all students can opt out or take courses in their own religion, or if in public schools only, code as 2 if in all schools, including private schools).

- Arrest, continued detention, or severe official harassment of religious figures, officials, and/or members of religious parties for activities other than proselytizing.

- State surveillance of minority religious activities not done on the activities of the majority.

- Restrictions on the ability to write, publish, or disseminate religious publications.

- Restrictions on the ability to import religious publications.

- Restrictions on the observance of religious laws concerning personal status, including marriage, divorce, and burial.

- Restrictions on wearing religious symbols or clothing. This includes the presence or absence of facial hair.

- Restrictions on the ordination of and/or access to clergy.

- Restrictions on conversion to minority religions.

- Forced conversions.

- Restrictions on proselytizing by permanent residents of state.

- Restrictions on proselytizing by foreign clergy or missionaries. (This includes denial of visas if this denial is specifically aimed at missionaries but not if it is the same type of denial that would be applied to any foreigner.)

- Requirement for minority religions (as opposed to all religions) to register in order to be legal or receive special tax status.

- Custody of children granted to members of majority group solely or in part on the basis of religious affiliation or beliefs.

- Restricted access of minority clergy to hospitals, jails, military bases, and other places a chaplain may be needed in comparison to chaplains of the majority religion.

- Anti-religious propaganda in official or semiofficial government publications.

- Restrictions on other types of observances of religious law. Specify: 